\title{
Thesis Title Eligibility Decision Support System using the Simple Additive Weighting Method at STMIK Palcomtech
}

\author{
Riki Maryono Apriando ${ }^{1}$, Lepian Mardinata², Barita Ardianto ${ }^{3}$ \\ 1,2,3Informatics Engineering Study Program, STMIK Palcomtech Palembang
}

\section{Article Info}

Article history:

Received: 01/07/2021

Revised: 29/07/2021

Accepted: $12 / 08 / 2021$

Available online 30/09/2021

\section{Keywords:}

Decision Support System (DSS), Simple Additive Weighting (SAW),

Prototype

\begin{abstract}
Decision Support System (DSS) is a system that can assist a person in making accurate and targeted decisions. Many problems can be solved using SPK, one of which is the feasibility of the thesis title at STMIK PalComTech Palembang. There are several methods that can be used in building a DSS including Simple Additive Weighting (SAW). As in the SPK the eligibility of the thesis title. This study uses the SAW method in determining the feasibility of the thesis title at STMIK PalComTech Palembang. In determining the feasibility of the thesis title, there are several criteria that become the basis for making decisions, including Journal, unique title, 5W 1H (What, Where, When, Why, Who and How)(Fitriani \& Alasi, 2020). Journal means whether the student fulfills all the journals to meet the eligibility requirements for the thesis title. A unique title means that students must be able to submit a title that has never existed or an existing title is then redeveloped so that it is not the same as the previous title. $5 \mathrm{~W} 1 \mathrm{H}$ is the title eligibility criteria that must be met. And in the development of the model using a prototype. The final result in this research is to get an assessment that is ordered from the lowest to the highest, so that the supervisor and the Head of Study Program can easily make decisions by looking at the results of the SPK.
\end{abstract}

This is an open access article under the CC BY-NC license.

\section{Corresponding Author:}

Riki Maryono Apriando,

Informatics Engineering Study Program, STMIK Palcomtech Palembang

E-mail: riki.maryono@gmail.com

\section{Introduction}

Decision Support System (DSS) as a computer-based system consisting of three interacting components, a language system (a mechanism for providing other decisions), a knowledge system (a repository of problem domain knowledge that exists in a decision support system or as data or procedures), and problem processing system (the relationship between the other two components, consisting of one or more general problem manipulation capabilities needed to take computers, law, psychology, etc.)(Ukkas, Pratiwi, \& Purnamasari, 2016) (Ghodsipour, 2017). The term thesis as a final project is only used in Indonesia, to complete education at a university, students must go through a final project (thesis) process.(Isyaca Fahmi, Prihandoko, \& Yulia Retnani, 2017) (Tuturoong, Sengkey, \& Najoan, 2016). Simple Additive Weighting (SAW) is often also known as the weighted addition method(Harsiti \& Roikotuljanah, 2017). The basic concept of this method is to find the weighted sum of the performance ratings for each alternative on all attributes(Chintyari \& Concern, 2018). The reason the author chose the Simple Additive Weighting (SAW) method.

Based on the description above, the author took the initiative to make a decision support system for the feasibility of the thesis title, as well as to complete the final assignment of the lecture the author 
conducted a research with the title "Decision Support System for the Eligibility of Thesis Title Using the Simple Additive Weighting (Saw) Method at Stmik Palcomtech".

\section{Method}

\subsection{Process Modeling}

At the process modeling stage, the author uses Data Flow Diagrams (DFD).

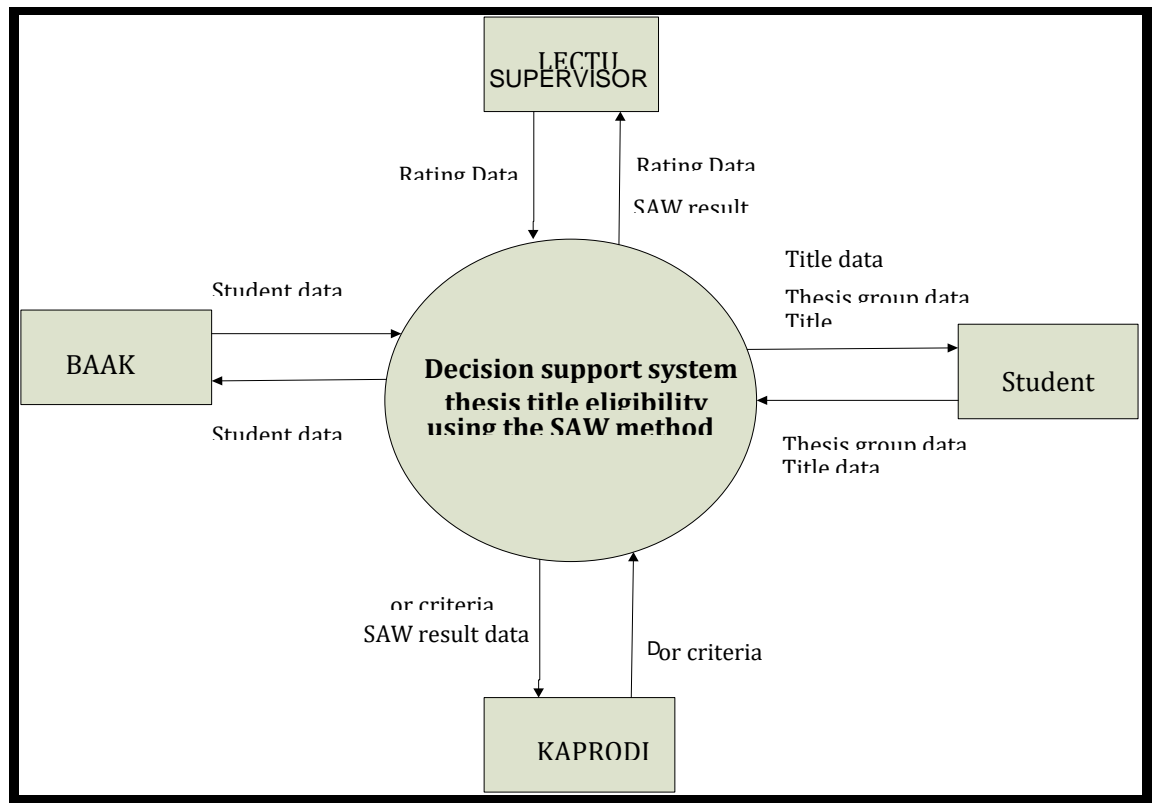

Figure 1. Context Diagram

Based on the context diagram in Figure 1, dAs can be explained, the process of submitting a thesis title at STMIK PalComTech Palembang has 4 external units, namely Advisory Lecturers, BAAK, Head of Study Programs and Students. Data sourced from BAAK is in the form of student data management. The data sourced from the Advisory Lecturer is in the form of information on submitting titles, SAW assessments, and SAW calculation results. Data sourced from students in the form of thesis group data, title submission data and the results of title recommendations. Data sourced from the Head of Study Program in the form of Criteria data and SAW results data.

\section{Results and Discussion}

\subsection{Interface Implementation}

Program coding for each display menu and submenu that has been designed using Microsoft Visual Basic. 


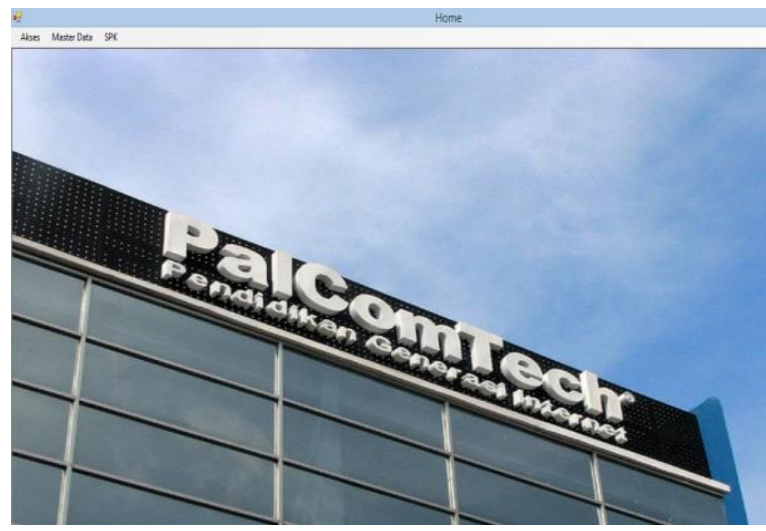

Figure 1.Menu

Picture 1 is the main menu display of the SPK for the feasibility of the thesis title at STMIK PalComTech, there are several menus, namely access, master, data, SPK.

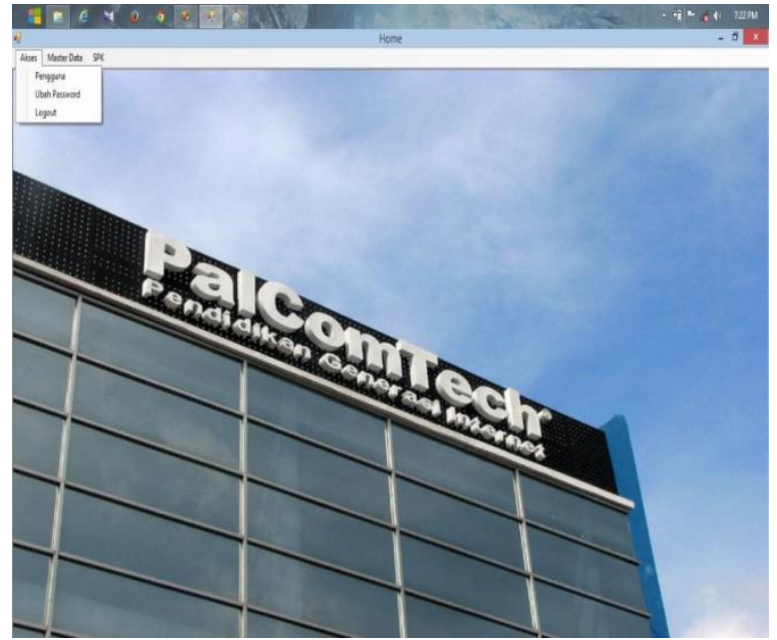

Figure 2.Access Menu

Figure 2 The access menu functions to create an administrator account and enter the application when the supervisor or head of the study program logs in and the administrator can change the password, change the password and there is also a logout to exit.

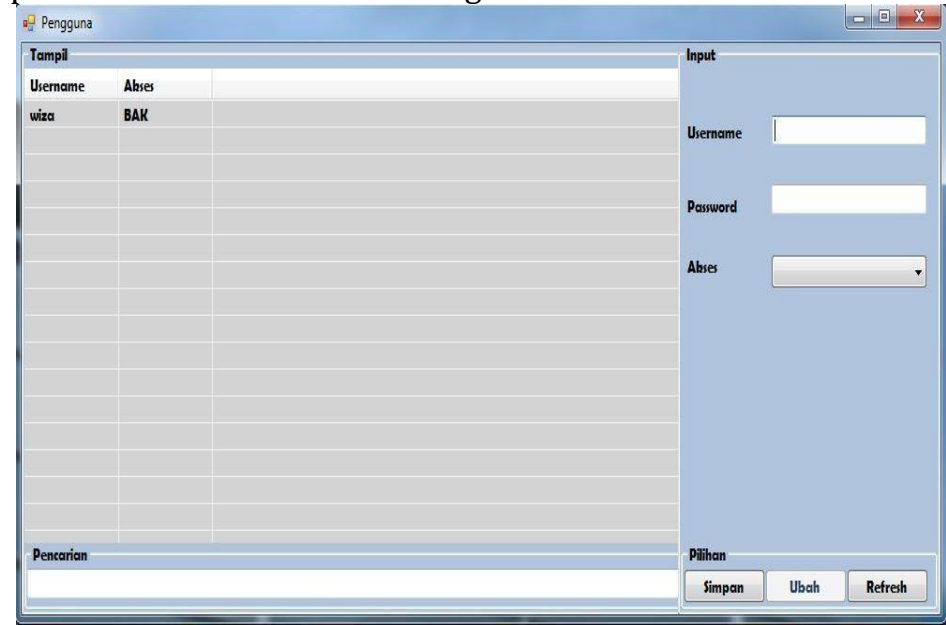

Figure 3.User Data 
Figure 3 users is where to create a new administrator and can be changed.

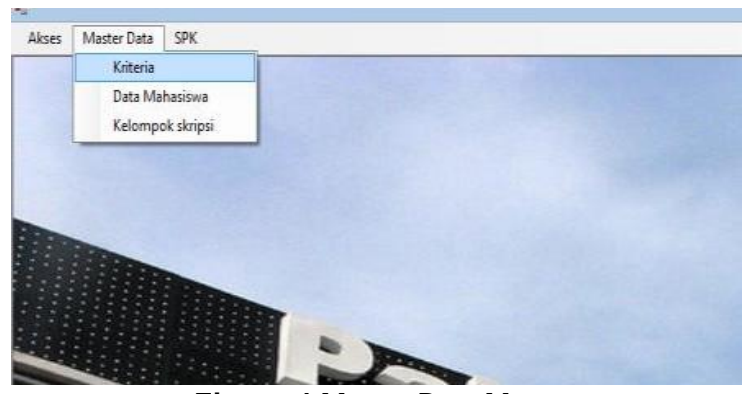

Figure 4.Master Data Menu

Figure 4 menu master data there is a submenu of student data criteria and thesis groups.

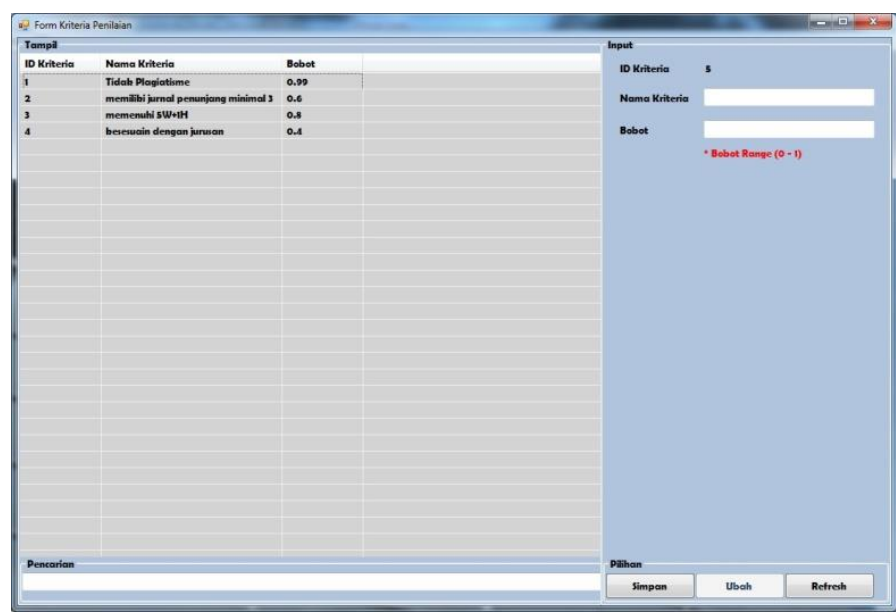

Figure 5.Criteria Data

Figure 5 criteria data are the components of title criteria in STMIK PalComTech and modified.

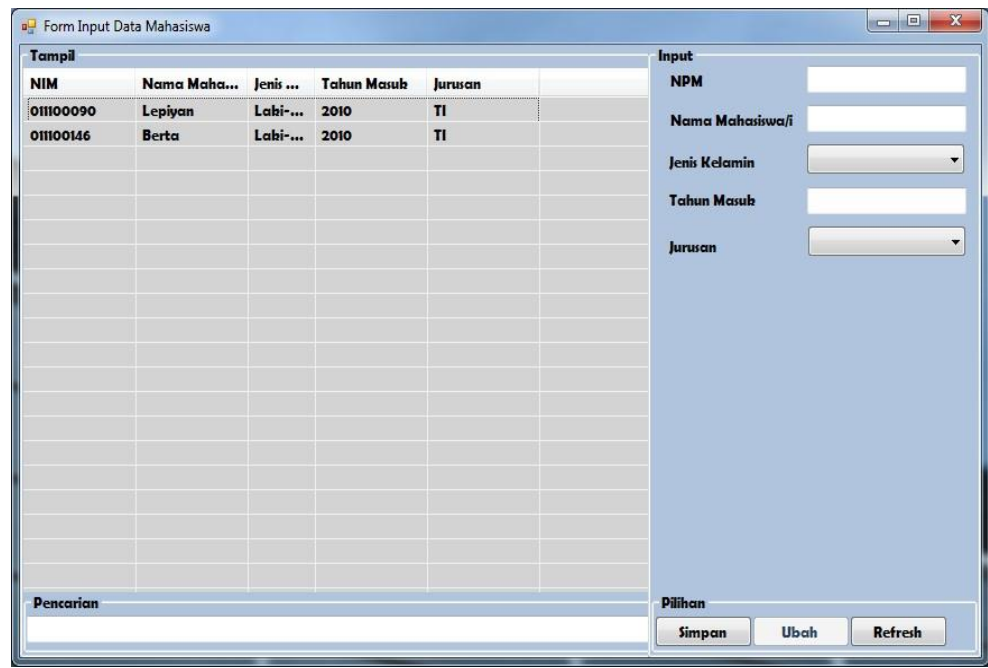

Figure 6.Student Data

Figure 6 Student data, namely inputting the names of students who are taking theses. 


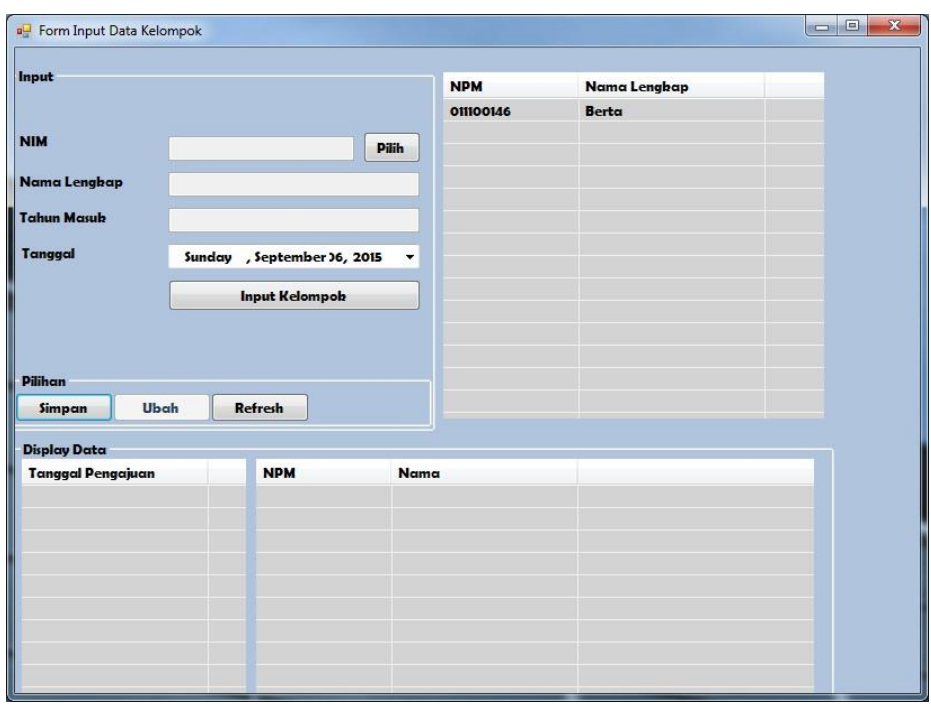

Figure 7.Thesis Group Data

Figure 7 thesis group selects the thesis group and will save it into the database.

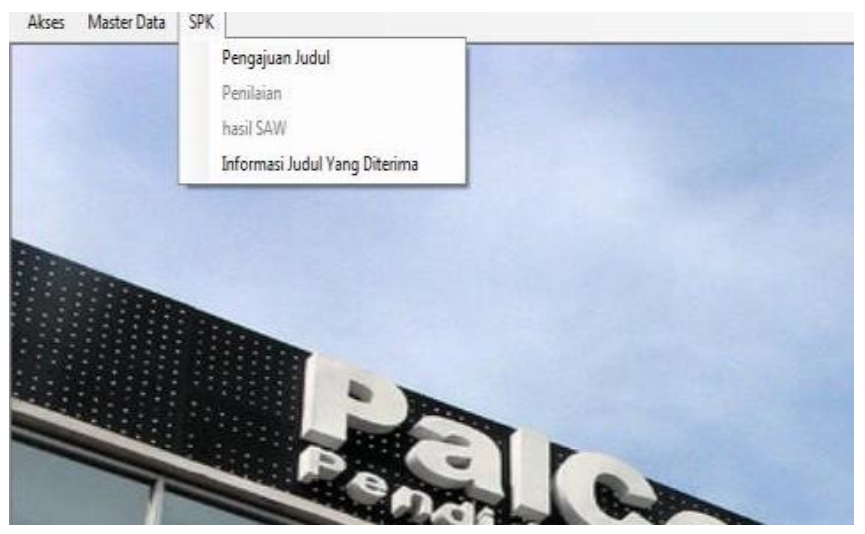

Figure 8.SPK menu

Figure 8 SPK menu contains submenus for title submission, assessment and SAW results and title information received. 


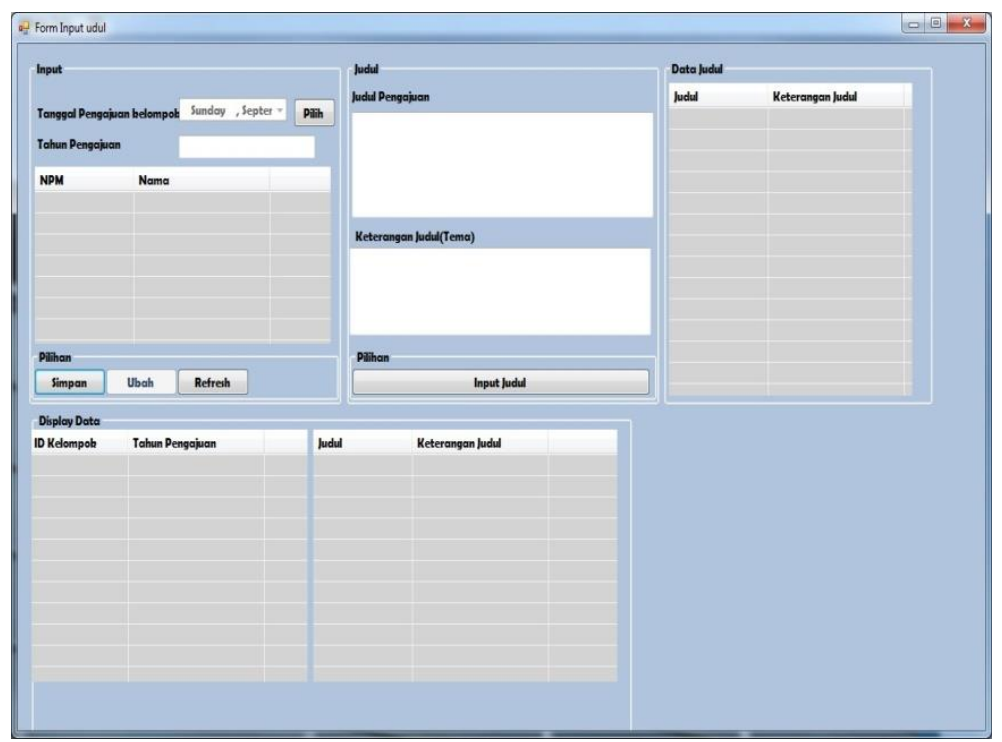

Figure 9.Title Test

Figure 9 submission of titles is selecting and entering the submission of title data for students or thesis groups.

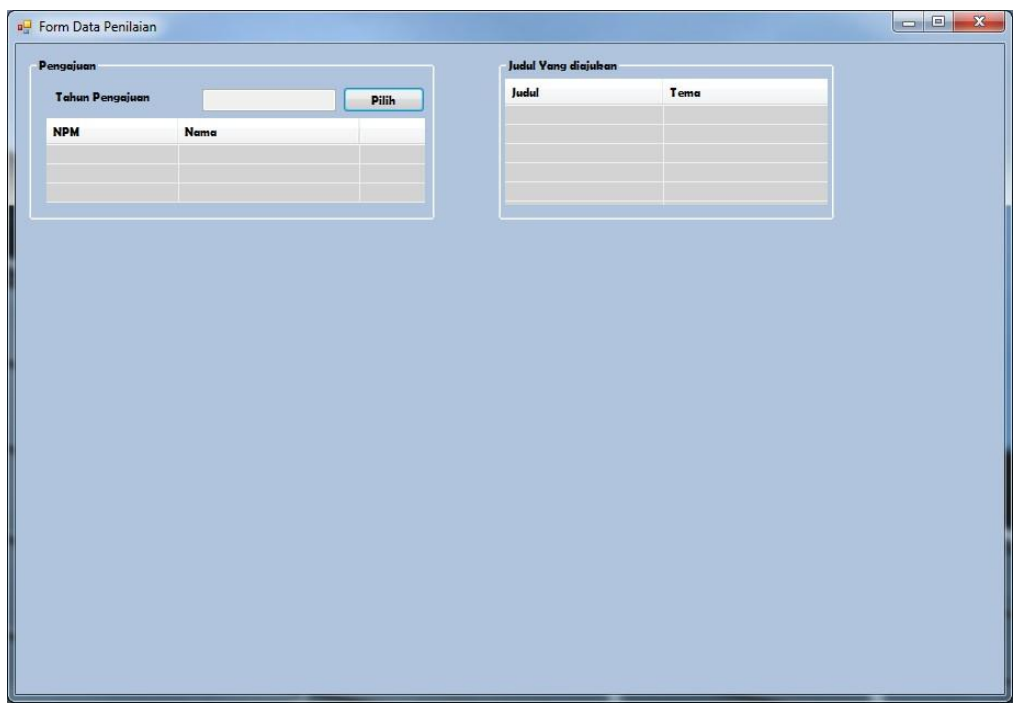

Figure 10.Evaluation

Figure 10 The assessment is giving a value to each title submitted by students based on the title criteria. 


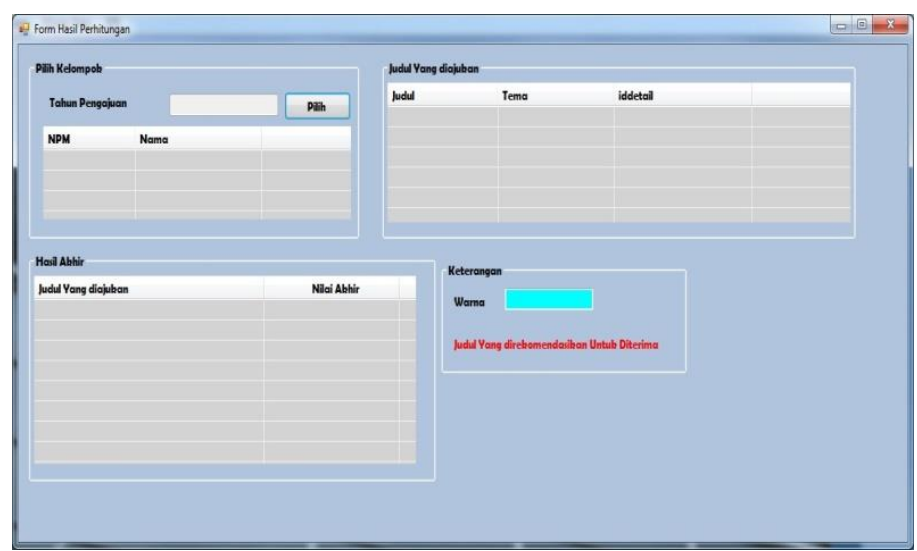

Figure 11.SAW results

Figure 11 The SAW results are the results of the calculation of the assessment of titles that have been given a value in each title, and it will be seen that the highest score is a recommendation for a proper title.

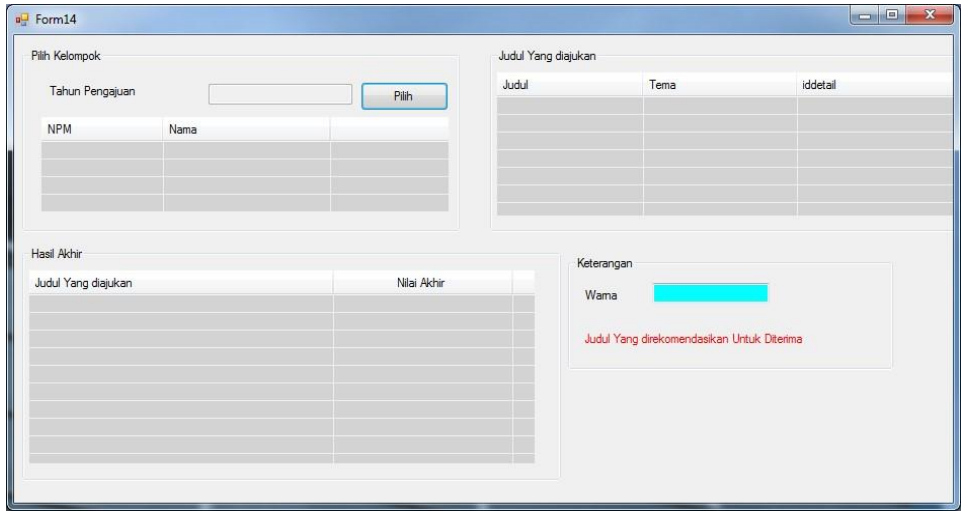

Figure 12.Received Title Information

\section{Conclusion}

With the application of a thesis title eligibility decision support system (SPK) using the SAW (simple additive weighting) method at STMIK PalComTech, it can make it easier for supervisors, the Head of Study Program to help determine the feasibility decision for the title of the thesis student who will submit the title to the supervisor and who determines it is appropriate. or not, the title is the supervising lecturer and the Head of Study Program. This title eligibility SPK is a desktop application made using the Microsoft Visual Basic programming language, and Microsoft Access as database storage, and the calculation of the title results using the SAW (simple additive weighting) method which can help supervisors and the Head of Study Program. So that the supervisor and head of study programs have no difficulty in determining the feasibility of the thesis title

\section{Reference}

Chintyari, Y. E., \& Prihatin, T. (2018). Implementasi Metode Simple Additive Weighting Untuk Pemilihan Guru Berprestasi Pada SMP Islam Pondok Duta. Jitk.

Fitriani, P., \& Alasi, T. S. (2020). Sistem Pendukung Keputusan dalam Menentukan Judul Skripsi Mahasiswa dengan Metode WASPAS, COPRAS dan EDAS berdasarkan Penilaian Dosen. Jurnal Media Informatika Budidarma.

Ghodsipour, H. (2017). RANCANG BANGUN SISTEM PENDUKUNG KEPUTUSAN PEMBERIAN PENGHARGAAN KARYAWAN DENGAN METODE AHP PADA PT BUMI CIKARANG STEEL INDUSTRIES. Jurnal Informatika SIMANTIK. 
Harsiti, H., \& Roikotuljanah, R. (2017). Sistem Pendukung Keputusan Pemberian Kredit Mikro Utama Pada Pt.Bank Bjb Kcp Cikande Dengan Metode Simple Additive Weighting (SAW). JSiI (Jurnal Sistem Informasi). https://doi.org/10.30656/jsii.v1i0.77

Isyaca Fahmi, N. R., Prihandoko, A. C., \& Yulia Retnani, W. E. (2017). Implementasi Metode Fuzzy AHP pada Sistem Penunjang Keputusan Penentuan Topik Skripsi (Studi Kasus : Program Studi Sistem Informasi Universitas Jember). BERKALA SAINSTEK. https://doi.org/10.19184/bst.v5i2.5533

Tuturoong, F. M., Sengkey, R., \& Najoan, X. (2016). Rancang Bangun Sistem Informasi Proses Tugas Akhir. Jurnal Teknik Informatika. https://doi.org/10.35793/jti.8.1.2016.12228

Ukkas, M. I., Pratiwi, H., \& Purnamasari, D. (2016). SISTEM PENDUKUNG KEPUTUSAN PENENTUAN SUPPLIER BAHAN BANGUNAN MENGGUNAKAN METODE SMART (SIMPLE MULTI ATTRIBUTE RATING TECHNIQUE) PADA TOKO BINTANG KERAMIK JAYA. Sebatik, 16(1). https://doi.org/10.46984/sebatik.v16i1.73 